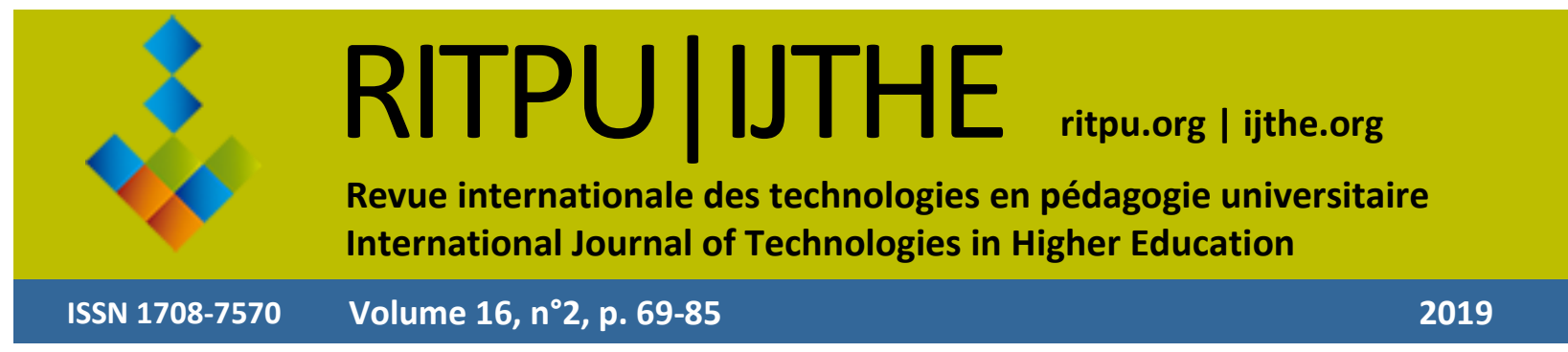

\section{Rethinking the relationship between plagiarism and academic integrity}

\section{Repenser la relation entre le plagiat et l'intégrité académique}

Sandra JAMIESON

Drew University, US sjamieso@drew.edu

Rebecca Moore HOWARD

Syracuse University, US rehoward@syr.edu

https://doi.org/10.18162/ritpu-2019-v16n2-07

\title{
Abstract
}

The term academic integrity is in widespread use, and while there has been much debate about what is included under that term and how we measure and encourage integrity in an academic context, no specific definition has been codified and universally accepted. This article reviews the historical evolution of the phrase through scholarship beginning in the 1960s, its shifting definition as an ethical or moral concept, and the ways in which it is currently being used, with a focus on the logics by which textual errors came to be classified as moral lapses. This article also provides analysis of students' textual errors as they work from sources. Based on these analyses, we advocate bringing together all cheating behaviors, including academic ghostwriting, under the umbrella of academic integrity and calling them cheating, plain and simple. At the same time, we contend that textual errors such as patchwriting and faulty citation should be removed from the moral category of academic integrity and treated as instances of bad writing to be remedied by pedagogy, not punishment.

\section{Keywords}

Academic ghostwriting; academic integrity; authorship; cheating; education; ethics; honesty; integrity; intertextuality; morality; plagiarism; patchwriting; pedagogy; transparency; writing instruction

\section{Résumé}

Le terme « intégrité académique » est largement utilisé, et bien qu'il y ait eu de nombreux débats sur ce qui est inclus sous ce concept et sur la façon dont nous mesurons et encourageons l'intégrité dans un contexte académique, aucune définition spécifique n'a été universellement acceptée. Cet article examine l'évolution historique du concept à partir des années 1960, sa définition changeante en tant que concept éthique ou moral, et les façons dont elle est 
actuellement utilisée, en mettant l'accent sur les logiques par lesquelles les erreurs textuelles en sont venues à être considérées comme des fautes morales. Cet article fournit également une analyse des erreurs textuelles des étudiants lorsqu'ils travaillent à partir de sources.

Suite à ces analyses, nous préconisons de rassembler tous les comportements de tricheries, y compris le prête-plume académique, sous le parapluie de l'intégrité académique et de les appeler tricherie, purement et simplement. En même temps, nous soutenons que les erreurs textuelles telles que le " patchwriting » et les citations erronées devraient être retirées de la catégorie morale de l'intégrité académique et traitées comme des cas de mauvaise écriture qui doivent être corrigés par la pédagogie, et non par la punition.

\section{Mots-clés}

Éducation; enseignement de l'écrit; éthique; honnêteté; intégrité; intégrité académique; intertextualité; moralité; patchwriting; paternité d'auteur; pédagogie; plagiat; prête-plume; transparence; tricherie

\section{Introduction}

With each development in the technologies available for the production and circulation of texts comes a new array of concerns about authorship, ownership, and textual appropriation. Indeed, Mark Rose (1994) claims that the very notion of "authorship" and related copyright only came about because of the invention of the printing press, when unfettered circulation of inexpensive texts threatened the English publishing status quo. We see a similar shift of attention from the freely circulating text to the textual producers--and reproducers--starting at the end of the twentieth century and coinciding with the ubiquity of the Internet. In 1921, T.S. Eliot could assert that while all poets "borrow" from others, what counted was the quality of the work produced with what they borrowed: "bad poets deface what they take, and good poets make it into something better" (p. 114). In contrast, today's conversations about "borrowing" and academic integrity are entirely focused on the person who does that borrowing; instead of judging the quality of the final text, they focus on the ethics or morals of the person who "borrowed" it.

The democratizing impact of the rise and expansion of the Internet has complicated intertextual practices in often conflicting ways. Words, ideas, and information are readily available at a click of a key to every writer with an Internet connection, increasing the circulation of knowledge and the depth of intellectual engagement. On the one hand, this allows words to be copied, both intentionally and accidentally, with greater ease, potentially increasing incidences of unauthorized textual borrowing. On the other hand, a simple phrase search easily reveals much of that copying, and commercial plagiarism detection software will perform this task for those who wish to pay for the service. In pre-Internet days, student plagiarists drew material from papers stored in the file cabinets of tutors, coaches, Greek-letter organizations, or paper mills without much chance of detection. Today, academic ghostwriting has moved online, where options are greater but discovery is easier.

With this shift comes a new concern about academic integrity. The debate about whether the Internet has caused or at least facilitated a rise in this kind of cheating is ongoing but anecdotal; to date, no large-scale study comparing papers produced before and after the arrival of the Internet has been conducted. While it is easier to catch such behavior now with Turnitin, and the 
Vroniplag Wiki (http://vroniplag.wikia.org/de), applications such as these do not provide sufficient evidence that more students are actually cheating or plagiarizing. Like the printing press, the Internet has produced an anxiety about the circulation of ideas and an urgency to develop ways to attribute "authorship" to those who deserve it - and root out imposters. Our terminology has shifted along with the technological shift.

The 19th-century discussion of copyright was economic; the 20th-century discussion of textual appropriation is ethical. And the umbrella term we use to categorize these conversations is academic integrity.

As might be expected from this brief history, the term academic integrity is one of relatively recent currency, with the first traceable usage appearing in William Bowers's 1964 dissertation. Since then, it has gained widespread usage, as evidenced in Tricia Gallant's 2008 Academic Integrity in the 21st Century: A Teaching and Learning Imperative; in Tracey Bretag's 2016 Handbook of Academic Integrity; and indeed, in the very title of this special issue.

Yet despite its currency, the term has no entry in the Oxford English Dictionary (2018). It is found neither in Merriam-Webster (2019) nor on Dictionary.com (2019). It has no entries in any of the specialized reference works compiled on Credo Reference (http://credoreference.com), either. How can such a common term in academic parlance have no dictionary or encyclopedia entries anywhere except in Wikipedia ("Academic Integrity", 2018)? Credo turns up plenty of entries in response to the search term "ethics," in places such as the Britannica Concise Encyclopedia, the Dictionary of World Philosophy, and the Encyclopedia of Postmodernism. But the term academic integrity, despite its commonplace use in key discourses that may result in punishment for those found lacking it, has not, as a term, been brought to the fore and codified. Values associated with academic integrity are listed by the International Center for Academic Integrity (ICAI, http://academicintegrity.org): "honesty, trust, fairness, respect, responsibility, and courage." The site does not, however offer a definition of the term in the portions available to the public without membership fees, and we have not found one quoted in published scholarship.

Although academic integrity still lacks an agreed-upon definition, many of the items generally classified under its umbrella are equally contested and some (most notably plagiarism) are responsible for much of the lack of consensus. We two researchers have invested considerable academic energy in the interrogation of other key terms in this field of inquiry. Howard (1992) examined the word plagiarism, acknowledging the moral issues involved in the purchase or downloading of papers written by someone other than the person submitting them (academic ghostwriting), but argued for a separation between such obvious acts of cheating and the phenomenon she named patchwriting. This latter describes students' failed paraphrases and summaries, which she analyzes one (Howard, 1995) in a rhetorical, intertextual framework rather than a moral one. Her work coheres with that of Shelley Angélil-Carter (2000), who observes: "plagiarism is a disputed concept, and . . . many instances of 'plagiarism' in student academic writing are not instances of intentional 'dishonesty,' 'theft' or 'immorality,' but problems of academic literacy" (p. 61). Jamieson (2016) traced those problems of academic literacy to the historical development of patchwriting as an educational concept, finding that examples of good summary writing provided in mid-twentieth-century North American textbooks and handbooks often actually contained patchwritten text-indications that educators' definitions of and attitudes toward patchwriting have been in flux (p. 512). She found, too, that those who conduct and read scholarly research on patchwriting tend toward "a growing sense ... that patchwriting is not intentional, not plagiarism, and not effectively dealt with through punishment" (p. 515). 
Both patchwriting and plagiarism are intertextual practices that do not fit easily into the honest/dishonest and ethical/unethical binaries that are most commonly associated with academic integrity. ${ }^{1}$

So as we undertake this contribution to a journal issue devoted to pedagogy supporting academic integrity, we find ourselves reflecting on - and now researching - the concepts underlying the term academic integrity. We conclude that, as is the case with the term plagiarism, the debate over what constitutes academic integrity obscures the very issues it tries to codify. In this article, we instead focus on the term academic integrity itself, first looking at its component parts, integrity and academic, and then exploring the genealogy of the term and its place in writing and information literacy instruction. We propose removing intertextuality practices (including some forms of what is currently categorized as plagiarism) from the honest/dishonest binary of academic integrity and student behavior and relocating them within writing pedagogy and textual practice. We advocate a pedagogical framework and an emphasis on teaching the literacies, intertextual skills, and intellectual practices that lead to textual engagement. Like grammar, spelling, and punctuation, whose rules students may not know or may sometimes knowingly or carelessly neglect, careless source attribution and incorporation produces bad writing and should be addressed as such. This leaves academic integrity guidelines to serve as institutional policy for the prevention and adjudication of unambiguous cheating. We believe that a clear separation between cheating (fabrication of data, copying on tests, contract cheating, purchasing or downloading papers, formulae or data and claiming authorship) and the intertextual practices that reveal a lack of critical thinking, literacy, or textual engagement will enable a globally useful consensus around issues of honesty and ethics.

These intertextual practices often take the form of patchwriting, close paraphrase, or cited copying, the very acts that muddy the category of academic integrity. They are indicators of a need for broader or deeper pedagogical interventions that take into account, and use, technological innovations and help students use technology wisely. Moving them from the judicial realm to the pedagogical realm leaves behind activities that are universally and unambiguously defined as cheating--activities that can never be defined as "accidental." Such a move invites ongoing research based not on counting incidences of cheating but on understanding students' writing and information literacy processes and determining where pedagogical interventions and improvements are necessary. Research into these issues has been undertaken by the Citation Project (http://citationproject.net), of which we are principal investigators. Additional research by Project Information Literacy (http://projectinfolit.org) and the Lilac Project (http://lilac-group.blogspot.com) offer additional opportunities for new and deeper understanding. The growing number of large collections of student papers like the Michigan Corpus of Upper-Level Student Papers (MICUSP, http://micusp.elicorpora.info), the British Academic Written English Corpus (BAWE, http://ota.ahds.ac.uk/headers/2539.xml) and the Uppsala Student English Corpus (USE, http://ota.ox.ac.uk/desc/2457) provide rich opportunities for additional studies of source use norms.

1. Graham Allen's (2003) book Intertextuality provides this perspective on the term: In traditional textual studies, reading and interpretation mean "extracting meaning from texts." Contemporary theory, in contrast, regards all texts as intertextual, "lacking in any kind of independent meaning" (p. 1). Celia Thompson's (2005) and Linda Hutcheon's (1986) work demonstrate how useful the concept of intertextuality is for thinking about the ways students use sources, and the negative ways in which readers may respond to those uses. 


\section{Globalization and the need for consensus}

We call for this reclassification of intertextual practices and cheating because without it, attempts to define the term academic integrity become hopelessly mired in the minutiae of local circumstances and politics, leaving no other choices than to attempt to itemize all things that could be considered academic integrity or to settle for general values and pass responsibility for definition to local actors. Despite its title, "Defining Academic Integrity," Tracey Bretag's introduction to her 1097-page Handbook of Academic Integrity (2016, p. 3-5) does the latter. The section that Bretag introduces, "International Perspectives" (p. 1-180), is comprised of 13 chapters by different authors offering descriptions and research on academic integrity practices and institutional responses in various countries (ranging from the UK to Japan) and regions (such as Glendinning's [2015] work on the EU). "Academic integrity," says Bretag in her introduction, "is such a multifarious topic that authors around the globe report differing historical developments which have led to a variety of interpretations of it as a concept and a broad range of approaches to promulgating it in their own environments." (p. 3). Contributors to the Handbook offer a number of references to, and listings of, the six values espoused by the International Center for Academic Integrity (ICAI) in place of a definition (Bretag, 2016, p. 147, 348, 415, 434, 467, 731, 981, 989, 997, 1010, 1062), and Gilmore, Maher, and Feldon (2016) provide an illustration of how these values are used in place of a definition. Having listed the ICAI values, Gilmore et al. continue, "Academic institutions attempt to translate these values into practice by creating policies and codes to which campus constituents should adhere" (p. 731).

Regarding the question of whether academic integrity is a foundational concept or a social construct, Bretag and her contributors make a clear though indirect argument for social construction. Undergirding Bretag's first section of the Handbook of Academic Integrity is the assumption that a definition of academic integrity can be established within regional or national cultures. As a social construct, though, such definitions always remain questionable and are always subject to challenge and revision. At first glance, this may seem unproblematic, even reasonable. Early scholarship on social construction tended to imagine a non-hierarchical, convivial process of generating consensus; however, the case of academic integrity reveals problems with such a vision. As Bretag's Handbook (to which we ourselves contributed) navigates the tension between this local consensus on the one hand while calling for a universal definition by international organizations such as the ICAI on the other hand, we see the elements of power, conflict, and cultural diversity in the processes of social construction identified by Mary Louise Pratt and others (Harris, 1997, p. 117). The same tension is at work in scholarly research on both plagiarism and academic integrity, the two poles of our title.

In the earliest scholarship on plagiarism and academic integrity, those who seek to measure and understand events classified by either term first feel called upon either to offer a definition, whether local or global (Bowers, 1964; Bretag, 2016; Harp and Taietz, 1966; Nuss, 1981, 1984) or to provide an extensive catalogue of examples from which a definition can be derived (Macfarlane, Zhang, \& Pun, 2012; Weber-Wulff, 2014). In this latter category, Macfarlane et al. (2012) provide an exhaustive literature review that endeavors to produce the universal definition that Bretag eschewed and to offer a compelling reason for a universal definition, although one that differs from the list promulgated by ICAI. Their detailed catalogue of categories of academic integrity revealed in the international literature on the subject is presented in response to what they describe as "the emergence of global university brands and influential international rankings [which] means that positive and negative perceptions of academic integrity can have a 
significant impact on institutional reputations" (p. 1). While more literature on the subject has been published since their 2012 review, and rapidly advancing technologies will undoubtedly add to the list, the argument remains compelling. Like John Harp and Philip Taietz's (1966) early and much-cited work on the topic, they see the development of norms of what constitutes academic integrity as fundamental for maintenance of "the stability and continuity of the academic system" p. 365). Theirs is an effort to create consensus through the sheer number of examples they offer, and thereby a stable standard that might be shared across institutions and contexts, minimizing accidental breaches of academic integrity when faculty, students, staff, and texts move across locales and contexts.

Publication, as these examples and this special issue of this journal highlight, is also global and in need of a shared standard of integrity. While Macfarlane et al.'s (2012) concern with "institutional reputation" is another matter, we take their reminder of the impact of the globalization of education and scholarship to heart. The risk of depending on locally defined academic standards is huge for students and scholars, opening them up to charges of ethical violations in one context that might be acceptable or considered minor breaches in another. For this reason alone it seems appropriate to agree upon some general principles governing a definition of the term academic integrity and to share it far and wide, as Macfarlane et al. and the International Center for Academic Integrity propose. Yet our methods toward that goal are in a sense contrary to those of both of these proponents; whereas the former provide a long list of types of academic dishonesty and the latter offers six character-traits or values around which policies can be developed, we focus our attention on categories themselves, in an effort to separate intertextual missteps from the moral category of academic integrity.

\section{A philosophical definition of integrity}

As we continue this examination of what is meant by the phrase academic integrity, it is helpful to pause and consider the core word in the phrase, the noun integrity-which in turn demonstrates why textual missteps commonly classified as "plagiarism" do not belong in the category of academic integrity, while cheating does. Appropriately, in 2001, the Encyclopedia of Ethics invited renowned moral philosopher Cora Diamond, Kenan professor of Philosophy Emerita at the University of Virginia, to write the key entry, "Integrity." Her contribution begins with this statement: "Integrity is ascribed to people, newspapers, works of art, nations, and other things, but it will be considered here simply as human virtue" [emphasis ours]. As she explains this claim, Diamond notes the inescapable elements of "moral identity," a "wholeness of self" entailed in integrity as human virtue. And indeed, the concepts of "wholeness of self" and "human virtue" inform the defining and policing of academic integrity by ICAI and many scholars and administrators. Diamond's definition begins with the statement, "Integrity is ascribed." Integrity, in other words, is a product of other people's evaluations of an individual's actions. This crucial part of the definition is in contrast to definitions of academic integrity as a set of values to be fostered and adopted by the individual. In Diamond's definition, the actions of individuals may diminish their ascribed moral identity. When we say integrity in this definition, then, we are speaking of what a specific community more or less agrees constitutes virtuous conduct.

Significantly for the issue of academic integrity, though, integrity in Diamond's analysis does not demand a flawless record: "It is . . . not to be expected that the virtue of integrity should be tied to acting [only] in ways that can independently be understood as morally appropriate or humanly desirable." Single actions, in other words, should not be mistaken as a proxy for the 
character of the actor. Rather, we should look at the collection of actions as "a story of someone's life." Yet in the policies and practices of academic communities across the globe, single actions all too often are taken as proxies for moral integrity when the word "academic" is added.

Diamond notes, "Reflective treatments of integrity by philosophers, writers, and literary critics (by moralists, in one sense of that term)... always involve reflection on the character of the relation between self and action." Her encyclopedia entry complicates and ultimately shows the limits of this "familiar technique." Yet the "moralists in one sense of the term" not only use the category of academic integrity for discussion of intertextuality practices, but also use the rhetorical moves in a text as a proxy for the morality of the actor, as if that equation were fundamentally unproblematic.

\section{A genealogy of the term academic integrity}

Diamond's discussion of the core term integrity helps explain a significant and problematic feature of many discussions of academic integrity: the interchangeable use of the terms integrity and honesty, as if they share the same meaning. This conflation is not a new move; in fact, a brief genealogy of the term academic integrity reveals it to have been passed down through generations of scholars on the topic. We see this in the first scholarly use of the term integrity (that we can trace) in relation to textual ethics, William J. Bowers's (1964) Columbia University dissertation, "Student Dishonesty and Its Control in College." Bowers notes on the first page, "The college or university is concerned not simply with imparting knowledge and ideas, but also with instilling a sense of integrity about academic work in its students." Later in the dissertation he asserts: "the individual's personal integrity or self-respect should be the basis for the decision not to cheat" (p. 69). In this conflation of terms, personal integrity equates with academic integrity, and "cheating" is cast as "dishonesty" and a violation of "self-respect." And so begins a citation trail up to the present day. Research by Charles Bonjean and Reece McGee in 1965 picks up on Bowers's findings regarding which populations are most likely to cheat. Bonjean and McGee use the sociological lens of deviancy to explore the context in which students engage in what they term scholastic dishonesty. Although they cite Bowers's research, they do not adopt his language of integrity, but they do cast cheating in the language of morality. Their argument provides a bridge to the first scholarly article we have found that makes significant use of the term academic integrity, John Harp and Phillip Taietz's "Academic Integrity and Social Structure: A Study of Cheating among College Students," published in the journal Social Problems in 1966.

In their own research into what McCabe Trevino, and Butterfield (1999) would later call "cheating behavior" (p. 212), Harp and Taietz cite the studies by Bowers (1964) and by Bonjean and McGee (1965) in a footnote (p. 365). They sign on to the notion of deviancy, equating it with a lack of academic integrity and explaining that cheating "involves a consideration of the norms to which the members of the system are oriented and subsequent deviation from the expectations of others" (p. 365). This foreshadows Diamond's definition of integrity as a descriptor applied to one individual by others in a specific social context. In language later picked up by Macfarlane et al., Harp and Taietz describe these "norms" as the very lifeblood of the academy. They assert that without norms of academic integrity, the stability and continuity of the academic system could not be maintained. Educators view any violation of the norms of academic integrity both as an ethical problem and as a negation of one of the objectives of education, i.e., the development of independent critical thinking. (p. 365) 
It is worth thinking through the dual role of academic integrity described by Harp and Taietz: they identify academic integrity as both an ethical or moral value and as evidence of "independent critical thinking." While Harp and Taietz echo Bowers's claim that one objective of a university education is to teach academic integrity, their addition of critical thinking would seem to diversify the conversation, preventing it from being addressed exclusively in ethical terms. Having named the moral and critical thinking aspects of academic integrity, however, Harp and Taietz do not go on to discuss that second aspect. Instead, their article focuses only on ethical/moral values, presenting cheating as always a deliberate choice rather than as a breakdown of independent critical thinking. In this manner they help to establish academic integrity as fundamentally an ethical issue. The ethical element lies in the notion of choice. Cheating is dishonest, and making a choice to cheat is demonstration of dishonesty. From here, Harp and Taietz's discussion of academic integrity uses the term dishonesty interchangeably with the term cheating, laying the groundwork for similar lapses in contemporary discourse and our struggle to offer a universal definition.

Elizabeth Nuss's award-winning 1981 dissertation, "Undergraduate Moral Development and Academic Dishonesty," cites these precursors but offers a slightly different take on the topic. Nuss addresses the issue not from the standpoint of the sociology of deviance but from that of the academic field of education. Her 1984 article, "Academic Integrity: Comparing Faculty and Student Attitudes" was published in the journal Improving College and University Teaching. As that journal's name suggests, Nuss takes the academic integrity discussion in a direction mentioned but not pursued by Harp and Taietz: critical thinking and learning. It is significant to our argument that Nuss's (1984) article uses the word "plagiarism" only once, in a discussion of the kinds of questions we should invite students to raise as we incorporate into the curriculum real discussions of academic integrity in the context of the purpose and expectations of higher education (p. 143). Also of relevance to our argument are the terms Nuss included in the survey she conducted among instructors and students. She identified fourteen items that she considered to be violations of academic integrity, ranging from "altering or forging an official university document" (which students considered to be the 3rd most serious offense, and which faculty ranked 8th) to copying and contract cheating (p. 142). While the word plagiarism does not appear on the list, Nuss identifies four items generally classified as plagiarism: "paying someone to write a paper to submit as your own work" (now often termed contract cheating or academic ghostwriting), "writing a paper for another student," "copying a few sentences without footnoting in a paper," and 'padding' a few items on a bibliography" (p. 142). Of those, students and faculty both ranked padding a bibliography as least important (14th out of 14). Not surprisingly, faculty ranked purchasing a paper as the second worst offense (after "copying from someone's exam paper without his or her knowledge"), while students ranked it as the fourth most serious offense. (For both faculty and students "Taking an exam for another student" and "having another student take an exam for you" ranked first.)

\section{Cheating Behaviors and Intertextual Missteps}

What may be most relevant about Nuss's (1984) findings is that both students and faculty ranked "copying a few sentences without footnoting in a paper" as the 12th most serious offense, with only "working on homework with other students when the instructor doesn't allow it" and "padding" ranking lower (p. 142). That these infractions are ranked as lesser, given the attention to this and other textual missteps known as patchwriting in current discussions, attests to changing patterns concerning what constitutes plagiarism. In 1984, "copying a few sentences" without citation was considered significantly less serious than purchasing a paper; in 1991, 
copying a few sentences with citation was being labeled as plagiarism (Hacker, 1991), even when the copy was not exact and words were rearranged or substituted. By 2014, Debora WeberWulff was devoting an entire chapter of her book on plagiarism to parsing different kinds of source integration that we would identify as patchwriting, all of which she categorizes as plagiarism although not in the context of penalties. Similarly, plagiarism detection software such as Turnitin codes texts for what it terms "originality," flagging duplicated words to derive an "originality score" but leaving instructors (or increasingly, administrators) to determine what is acceptable, based on the kind of locally determined rules we argue against in this article.

As the absence of cited patchwriting from the studies conducted by Bowers, Nuss $(1981,1984)$ and Harp and Taietz suggests, educators have not always classified patchwriting as academic dishonesty. In "Is it Plagiarism or Patchwriting? Toward a Nuanced Definition," Jamieson (2016) offers an historical account of the classification of patchwriting as academic dishonesty. In the mid-twentieth century, scholarship and textbooks in the US talked about summary and quotation, but seldom about paraphrase. When North American textbooks (including the 1977 MLA style guide) did begin providing examples of paraphrase, many of those examples would now be classified as patchwriting. By the end of the century, writers' handbooks in a variety of disciplines included not only guidelines for paraphrase but also advice about how to avoid plagiarizing while paraphrasing (p. 509). Whereas the sample summaries in mid-twentiethcentury US textbooks and handbooks often contained patchwriting, it is now common to see academic integrity policies that specify patchwriting (regardless of whether that term is itself used to label the textual practice of too-close paraphrase) as a violation of academic integrity, sometimes labeled as "unintentional plagiarism," but classified as plagiarism nonetheless. This criminalization of patchwriting, Jamieson says, is part of a movement over the past 75 years toward increasingly tight, codified strictures against academic dishonesty.

It may also be part of the increasing corporatization of US universities. In a 2016 article in the journal Ethics and Behavior, Bradford Barnhardt describes the "behavior inventories" that constitute academic codes of conduct. These inventories are, he points out, for administrative purposes, rendering "the prevention of excuses more of a policing issue than a moral or theoretical one" (p. 339). We see this administrative agenda also at work in the lists produced by Macfarlane et al., whose concern is for the overall health of higher education rather than for student learning or critical thinking per se. We also see it in the widespread adoption of plagiarism detection software to check for a lack of "originality" without a full understanding of how to "read" the results.

It is this broadening of the term cheating to include patchwriting and other activities in the grey area between intentional and unintentional that is our concern. If academic integrity is another way of referring to what Bowers $(1964$, p. 1) calls "the decision not to cheat," that is, if it refers to intentional ethical and moral violations of community standards, then the terms academic integrity and cheating do not and should not be used interchangeably with the term plagiarism. While Bowers's definition clearly links academic integrity and intent, in the case of plagiarism that link-like the definition itself--is not always clear.

2. Amanda McKenzie (personal communication. April 30, 2019) points out that one of the most popular plagiarism detection programs, Turnitin, does provide guidelines for the interpretation of originality scores and stresses the importance of careful review of the score and flagged content to differentiate between quoted material and uncited copying. However, as with other programs, the nuance between copying and patchwriting is easily lost (see Weber-Wulff, 2019). More education about the use of this software may help instructors/administrators use it appropriately, but only if these nuances are clarified and addressed. 
To remedy that problem, we do not recommend redefining plagiarism, but eliminating the term entirely, with all of the intertextual acts broadly included under the term academic integrity removed and moved into a separate, pedagogical arena. Whether students can paraphrase, summarize, quote, and cite well is a matter of writing instruction, along with critical thinking and reading skills - what Diamond identifies as the writer's "life story" - not a sign of the writer's moral character. Longitudinal studies of graduate student writers in several different countries, disciplines, and educational systems show that as they become more deeply enculturated into their academic environment, citation missteps decrease (see summary of research in Jamieson, 2018, p. 111-119). Citation Project research reveals that many students are able to paraphrase effectively some of the time, slipping back and forth between patchwriting and paraphrase as shown in Figure 2 (see also Jamieson \& Howard, 2013), just as most students are capable of editing sentences and paragraphs more effectively than they actually do in many papers. The "choice" may be one of how much time or effort to expend rather than how to be more ethical. To be clear: we do not regard any form of contract cheating or academic ghostwriting as plagiarism. We regard it as cheating, and cheating is a separate category from intertextual missteps.

Intertextual missteps can be addressed in multiple ways. One method described by Cassandra Sachar (2018) in Inside Higher Ed is to use Turnitin as a pedagogical tool to help students check their own originality. She includes an example of a student text to illustrate the process (In Figure 1). The student takes 12 words from the original 39, replacing "some" with "many" and compressing "rabbits, hamsters, guinea pigs and rodents" into "animals." Sachar observes that "when comparing the student paper to the original source, it is easy to tell why Turnitin highlighted as it did." She adds, "once patch writing has been detected, students need tools to alter their wording," and then proceeds to discuss paraphrase and summary. In the second part of Figure 1, Sachar's example has been coded using the methods of visual analysis that we developed for the Citation Project. Defining the material in Figure 1 as "patch writing" is a far cry from "copying a few sentences without footnoting in a paper," which Nuss's research found to be low on the list of concerns in 1984.

Sachar's argument that the appropriate response to text like this in a draft should be pedagogical aligns with our own thinking. But the article is entitled "Using Turnitin to teach students not to plagiarize," suggesting that in a final draft, what she identifies as "patch writing" might lead to the writer being classified as a plagiarist, even though only a few decades ago, such errors were classified, even by the Modern Language Association, as satisfactory paraphrase, even summary. If this implication is the way she would proceed, Sacher would be in line with others who use Turnitin's originality scores - against the advice of many of the spokespeople for the organization. According to Weber-Wulff (2019), "Universities formally define 'acceptable' levels of plagiarism, evaluated by the software, for various degree levels" (p.435). And they are not alone. Weber-Wulff continues, "journal editors use the numbers as a crutch to quickly filter out papers that they can reject outright, or that they can publish without worry if reviewers give a thumbs up. Some journals and conferences even publish their threshold online" (p. 435). As an example, she offers, "abstracts submitted to the World Conference on Research Integrity [in 2019] were analysed by software, with a text-overlap threshold set at 30\%" (p.435). Thus does intertextual misstep become cheating. 
Figure 1: Student text coded as unoriginal by Turnitin, from Sachar, Cassandra O'Sullivan. "Using Turnitin to Teach Students Not to Plagiarize," Inside Higher Ed, April 10, 2018

\begin{tabular}{|c|c|c|}
\hline & Student text as quoted by Sachar & Source text as quoted by Sachar \\
\hline & $\begin{array}{l}\text { Many companies will test their products by } \\
\text { forcing animals to breathe in poisonous } \\
\text { chemicals while also having lethal substances } \\
\text { poured in their eyes and rubbed in their skin } \\
\text { (Cole, 2015) }\end{array}$ & $\begin{array}{l}\text { It is awful that some companies still test their } \\
\text { new products and ingredients by forcing rabbits, } \\
\text { hamsters, guinea pigs and rodents to suffer } \\
\text { through horrific practices such as breathing in } \\
\text { poisonous fumes or having lethal chemicals } \\
\text { rubbed onto their skin. (para. 13) }\end{array}$ \\
\hline & $\begin{array}{l}\text { Student text with copied words double underlined } \\
\text { and transformed /substited word underlined once }\end{array}$ & $\begin{array}{l}\text { Student text with copied words double underlined } \\
\text { and transformed /substited word underlined once }\end{array}$ \\
\hline & $\begin{array}{l}\text { Many companies will test their products } \underline{\underline{\text { by }}} \\
\text { forcing animals to breathe in poisonous } \\
\text { chemicals while also having lethal substances } \\
\text { poured in their eyes and rubbed in their skin } \\
\text { (Cole, 2015) }\end{array}$ & $\begin{array}{l}\text { It is awful that some companies still test their } \\
\text { new products and ingredients by forcing rabbits, } \\
\text { hamsters, guinea pigs and rodents to suffer } \\
\text { through horrific practices such as breathing in } \\
\text { poisonous fumes or having lethal } \underline{\text { chemicals }} \\
\text { rubbed onto their skin (para. 13) }\end{array}$ \\
\hline & \multicolumn{2}{|c|}{$\begin{array}{l}\text { ORIGNAL SOURCE: Cole, Natacha, "It Is Time Canada Banned Cosmetic Animal Testing," } \\
\text { Huffington Post. 12/23/2015 }\end{array}$} \\
\hline
\end{tabular}

\section{Academic Integrity, Morality, and Intentionality}

The work of Donald McCabe and his various coauthors in the 1990s (McCabe \& Trevino, 1993; McCabe, Trevino, \& Butterfield, 1999) seems to stand as a significant bridge in the progression from Nuss's relatively low level of concern about plagiarism in 1984 to Weber-Wulff's absorption with it in 2014 and to Sachar's use of Turnitin in 2018. McCabe and Linda Trevino cite Harp and Taietz (1966), Nuss (1984), and Bowers (1964) in a 1993 article that is sometimes incorrectly identified as having made the first use of the term academic integrity. The title of that article is "Academic Dishonesty: Honor Codes and other Contextual Influences," and in it they identify academic integrity policies, codes of conduct, and classes as "contextual influences" that can affect whether students behave dishonestly.

For McCabe and Trevino, dishonesty and cheating describe student behavior. Academic integrity describes institutional policies and practices designed to stop cheating and is used interchangeably with the term academic honesty (as in "academic honesty policies"). Although focused on the value of institutional measures, McCabe and Trevino note that "it is possible for institutions of higher education to create a strong climate supportive of academic integrity" without having "an explicit honor code" if students are aware of the sanctions for violation and if academic integrity rules and guidelines are enforced effectively (p. 526). Academic integrity, for them, is 
- a collection of "contextual influences" that reduce cheating

- the climate created by that reduction

- student behavior within that climate

It follows, then, that students who violate policies and norms do so because they are dishonest, and the implication is that if they know there are serious penalties, they will not cheat. McCabe and Trevino propose education about academic integrity policies and the frightening consequences of violating them, rather than the kind of education about critical thinking proposed by Bowers, or the broader educational project described by Nuss (1984). Their work, then, is of a piece with the studies of cheating as deviancy.

McCabe and Trevino, joined by Kenneth Butterfield, explored this idea further in 1999 in an article whose title specifically names academic integrity in relation to honor codes as its object of study. This article, though, does not include the term plagiarism in its discussion of cheating. McCabe and Trevino's 1993 article mentions the word once in a description of a study of peer behavior in which students were asked "how frequently (never to very often on a five-point scale) either plagiarism or test cheating occurred at their school" (p, 531). These two categories ("cheating on tests" and "cheating on term papers and reports") were also named by Harp and Taietz as "forms of cheating essentially agreed upon by faculty and students as comprising a class of acts which violate norms of academic integrity" (p. 366). Harp and Taietz's research focuses on the latter because " 50 per cent of all students reported cheating on term papers" (p. 367), although they neither identify what they mean by "cheating on term papers" nor use the term plagiarism.

Importantly, labeling certain acts that violate standards and codes of academic integrity as cheating without using the term plagiarism informs our argument in this article. It is possible to consider "cheating behavior," as these scholars do, as a choice, e.g., purchasing a paper and submitting it as one's own. It is also possible to generate long lists of other behaviors that violate agreed academic standards of integrity, as do Macfarlane et al. (including everything from faculty-student relations to behavior in labs). Things become more complicated, however, when we try to classify plagiarism beyond the obviously deliberate. The kind of cheating described by all of these scholars when they use the term academic integrity does not include the more subtle forms of failed intertextuality practices that are included in the subcategory of plagiarism that is now often labeled patchwriting.

Barnhardt (2016) is particularly opposed to interpreting a student's violation of an item in a behavior inventory as a sign of the student's personal lack of morality (p. 331). He offers two reasons for separating the morality of an act from the morality of an actor: students may not know that what they are doing is transgressive; and they may have their own scale for measuring the severity of academic infractions, a point of view supported by Susan Blum's 2009 ethnographic investigation of students' attitudes toward college writing assignments, as well as by Elizabeth Nuss's 1984 survey of students' and instructors' attitudes toward academic integrity.

\section{From writer to text}

In our own Citation Project research, we have moved from an early focus on the actions of the writer to a focus on what is happening in the text. Written in 1992, Howard's initial definition of patchwriting, "Copying from a source text and then deleting some words, altering grammatical 
structures, or plugging in one-for-one synonym-substitutes" (p. 233) was focused on what the writer does. Our more recent Citation Project work, however, led us to adopt a text-based rather than a writer-based definition: in patchwriting, the text "restates a phrase, clause, or one or more sentences while staying close to the language or syntax of the source" (Jamieson, 2018, p. 110). Jamieson describes how this shift from writer to text took place as the 25 coders of Citation Project data, working with Howard's writer-centered definition of patchwriting, fell prey to confirmation bias (p. 109-110). As Jamieson notes, the revised definition of patchwriting, which speaks in terms of what the text rather than what the writer does, is value-neutral and does not encourage character judgments about the student writer, making no guesses about the choices open to and made by the student.

In other words, our research, as well as our reading of others' research, has led us to move our attention from the morality of the writer to the rhetorical actions involved in intertextual writing. This is an evidence-based, logical shift, but it is one that runs afoul of contemporary trends toward administratively-driven policy development. Our change in focus underscores the complex realities of intertextual, source-based writing. Our objective is to foster writers' engagement with the sources they use in their work. To classify patchwriting or other textual missteps as a moral failure interferes with that work, and that misclassification in fact has no supporting data.

Our research is also contextual. Rather than fetishizing one incidence of source use (or misuse)—_single actions," as Diamond would term them - we look at source use in the context of the entire paper. We code each citation by hand and then look at them together as a whole, not as potential infractions but as evidence of students' facility (or lack thereof) in engaging and incorporating source material in naturalistically produced text. That shift, from fetishizing isolated citations to analyzing citations in context, reveals patterns of patchwriting, paraphrase, summary, and quotation co-occurring within contained passages in students' work, as those student writers wrestle their sources into their "own" texts. The sample in Figure 2 shows the trend: Here the writer of paper Z07 (a code used by the Citation Project to anonymize student writers) begins with summary; then shifts to patchwriting. Within the 1,811 citations in 174 papers collected from 16 colleges across the US that we coded and studied in the first wave of Citation Project research, we find such shifts so common that it is difficult to conclude anything other than that the student writer may be unaware of the movement away from and toward the source language. 


\begin{tabular}{|c|c|c|}
\hline \multicolumn{3}{|c|}{$\begin{array}{l}\text { Figure 2: Sample from a source text and student paper, with marginal notations of how the source is } \\
\text { being used. Summary of the source is indicated in boldface; patchwriting from the source is } \\
\text { underlined (double underline signifies words exactly copied, single underline indicates word } \\
\text { substitutions - "meant to" for "purpose" for example) }\end{array}$} \\
\hline & $\begin{array}{l}\text { Student text (consecutive sentences from one } \\
\text { paragraph on } p .3 \text { of the paper) }\end{array}$ & $\begin{array}{l}\text { Source text (non-consecutive passages from } \\
\text { pages 424-425 of The Sacred Willow: Four } \\
\text { Generations in the Life of a Vietnamese Family) }\end{array}$ \\
\hline 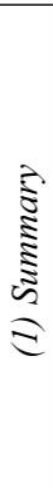 & $\begin{array}{l}\text { First, the government tried to build their power } \\
\text { over the economy to enforce economic equality } \\
\text { and eradicate capitalism. The process was divided } \\
\text { into two movements: the currency conversion and } \\
\text { the attack at businessmen. First, right after the } \\
\text { new authority was established in the South, }\end{array}$ & $\begin{array}{l}\text { The next move for the government was to smash } \\
\text { businessmen and entrepreneurs. This happened in } \\
\text { two waves. At first, the big capitalists were } \\
\text { targeted. The biggest of them all-Hoang Kim } \\
\text { Quy, who had been known as the king of iron and } \\
\text { steel-was arrested and sentenced to twenty years } \\
\text { in jail, because he had produced the barbed wire } \\
\text { used by the Saigon army. The second wave came } \\
\text { in } 1978 \text { and focused on merchants. }\end{array}$ \\
\hline 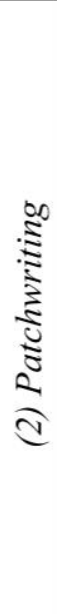 & $\begin{array}{l}\text { the currency conversion happened suddenly to } \\
\text { prevent people from subverting it. Keeping in mind } \\
\text { that most of the upper class had fled the country, } \\
\text { the conversion was meant to wipe out the savings } \\
\text { of the middle class and upper middle class in order } \\
\text { to bring them down to the level of the poor to } \\
\text { achieve economic equality. In the end, every } \\
\text { household could get up to } 200 \text { piasters in the new } \\
\text { currency despite how much money they previously } \\
\text { had (Elliot 424). }\end{array}$ & $\begin{array}{l}\text { The currency conversion happened suddenly, to } \\
\text { catch everyone off guard and prevent people from } \\
\text { subverting it. Its purpose was to wipe out the } \\
\text { savings of the middle and upper middle class, and } \\
\text { therefore reduce them to the level of the poor in } \\
\text { order to achieve economic equality.... } \\
\text { In the end, each household could get at most } 200 \\
\text { piasters in new money-actually a big sum } \\
\text { considering how much each piaster could buy- } \\
\text { even if the number of people living in it entitled } \\
\text { them to more. }\end{array}$ \\
\hline & \multicolumn{2}{|c|}{$\begin{array}{l}\text { STUDENT CITATION: Elliott, Duong Van Mai. The Sacred Willow: Four Generations in the Life of } \\
\text { a Vietnamese Family. New York: Oxford UP, 1999. Print. }\end{array}$} \\
\hline
\end{tabular}

\section{Conclusion: Morality and Transparency}

Diamond (2001) concludes her definition of integrity with the following: "One's understanding of one's life and who one is can be in an act, but showing what it is for this to be so, which is essential to showing what integrity is, means not focusing ... on acts and choices detached from the life story to which they belong." Writing from sources is a rhetorical, intertextual experience, not a moral act or series of disconnected acts that can be judged in isolation from each other. The more experience writers have in working from sources, the more likely they are to be able to accomplish this complex work transparently. The transparent use of sources is a more accurate and more productive frame for all the intertextual missteps typically labeled plagiarism. As Angélil-Carter (2000) notes, "there are a range of underlying causes for plagiarism in student writing, few of which seem to be intention to deceive" (p. 113).

The term plagiarism has no place in the category of academic integrity, and to link the two together prevents attention to the rhetorical education and experiences needed for excellent 
writing from sources. The criminalization of missteps makes this a terrifying rather than satisfying learning experience for students.

There is one sort of activity that should be exempted from what we've just said: contract cheating, downloading term papers, or otherwise knowingly submitting someone else's whole texts and claiming authorship of them. Too often these are miscategorized as plagiarism. Let us be clear: students who submit under their own name papers that were actually composed by someone else are cheating. This is a moral issue that obviously belongs in the category of academic integrity. All the other intertextual missteps that are labeled plagiarism, such as failure to cite extracted material, failure to correctly mark quotations, and patchwriting, are what Diane Pecorari (2003, p. 342) termed non-transparent source use and are not a violation of academic integrity. They are not good writing. But they are also not immoral acts, unless the reader (the instructor, presumably) has evidence beyond the text that the writer is deliberately trying to deceive. For the reader who encounters any of these missteps to assume unethical intentions on the part of the writer - as so many college academic integrity policies do, indeed, insist upon—is itself unethical.

\section{References}

Academic integrity (2018, November 12). In Wikipedia. Retrieved from http://en.wikipedia.org

Allen, G. (2000). Intertextuality. London, UK: Routledge.

Angélil-Carter, S. (2000). Stolen language? Plagiarism in writing. New York, US: Longman.

Barnhardt, B. (2016). The 'epidemic' of cheating depends on its definition: A critique of inferring the moral quality of 'cheating in any form.' Ethics \& Behavior, 26(4), 330-343. doi:10.1080/10508422.2015.1026595

Blum, S. D. (2009). My word! Plagiarism and college culture. Ithaca, US: Cornell University Press.

Bonjean, C. M., \& McGee, R. (1965). Scholastic dishonesty among undergraduates in differing systems of social control. Sociology of Education, 38(2), 127-137. doi:10.2307/2112195

Bowers, W. J. (1964). Student dishonesty and its control in college. New York, US: Columbia University Bureau of Applied Social Research.

Bretag, T. (Ed.). (2016). Handbook of academic integrity. Singapore: Springer. doi:10.1007/978981-287-079-7

Diamond, C. (2001). Integrity. In L. C. Becker \& C. B. Becker (Eds.), Encyclopedia of ethics / 2 (2nd ed.). New-York, US: Routledge.

Eliot, T. S. (1921). The sacred wood. Essays on poetry and criticism. New York, US: Knopf.

Gallant, T. B. (2008). Academic integrity in the 21st century: A teaching and learning imperative (ASHE higher education report, vol. 33, no. 5). Hoboken, US: Wiley.

Gilmore, J., Maher, M., \& Feldon. D. (2016). Prevalence, prevention, and pedagogical techniques: Academic integrity and ethical professional practice among STEM students. In T. Bretag (Ed.), Handbook of academic integrity (pp. 729-748). Singapore: Springer. https://doi.org/10.1007/978-981-287-079-7_45-1 
Glendinning, I. (2015). European perspectives of academic integrity.In T. Bretag (Ed.), Handbook of academic integrity (pp. 55-74). Singapore: Springer. https://doi.org/10.1007/978-981-287-079-7_3-2

Hacker, D. (1991). The Bedford handbook for writers (3rd ed.). Boston, US: Bedford.

Harp, J., \& Taietz, P. (1966). Academic integrity and social structure: A study of cheating among college students. Social Problems, 13, 365-73. doi:10.2307/798585

Harris, J. (1997). A teaching subject: Composition since 1966. Upper Saddle River, US: Prentice Hall.

Howard, R. M. (1993). A plagiarism pentimento. Journal of Teaching Writing, 11(3), 233-45. Retrieved from http://journals.iupui.edu/index.php/teachingwriting

Howard, R. M. (1995). Plagiarisms, authorships, and the academic death penality. College English, 57(7), 788-806. Retrieved from SURFACE: Writing Program Series: http://surface.syr.ed

Hutcheon, L. (1986). Literary borrowing . . . and stealing: Plagiarism, sources, influences, and intertexts. English Studies in Canada, 12(2), 229-39. Retrieved from TSpace repository: http://tspace.library.utoronto.ca

Jamieson, S. (2016). Is it plagiarism or patchwriting? Toward a nuanced definition. In T. Bretag (Ed.), Handbook of academic integrity (pp. 503-518). Singapore: Springer. https://doi.org/10.1007/978-981-287-079-7_68-1

Jamieson, S. (2018). Shouldn't our expectations of students' and academics' intertextuality practices differ? In D. Pecorari \& P. Shaw (Eds.), Student plagiarism in higher education: Reflections on teaching practice (pp. 105-122). London, UK: Routledge. doi:10.4324/9781315166148

Jamieson, S., \& Howard, R. M. (2013). Sentence-mining: Uncovering the amount of reading and reading comprehension in college writer's researched writing. In R. McClure \& J. P. Purdy (Eds.), The new digital scholar: Exploring and enriching the research and writing practices of NextGen students (pp. 111-133). Medford, US: Information Today. Retrieved from the Citation Project website: http://citationproject.net

Macfarlane, B., Zhang, J., \& Pun. A. (2012). Academic integrity: A review of the literature. Studies in Higher Education, 39(2), 339-358. doi:10.1080/03075079.2012.709495

McCabe, D. L., \& Trevino, L. K. (1993). Academic dishonesty: Honor codes and other contextual influences. Journal of Higher Education, 64(5), 522-538. doi:10.1080/00221546.1993.11778446

McCabe, D. L., Trevino, L. K., \& Butterfield, K. D. (1999). Academic integrity in honor code and non-honor code environments: A qualitative investigation. Journal of Higher Education, 70(2), 211-234. doi:10.1080/00221546.1999.11780762

Nuss, E. M. (1981). Undergraduate moral development and academic dishonesty (Ph. D. dissertation, University of Maryland, US). Retrieved from DRUM repository: http://drum.lib.umd.edu

Nuss, E. M. (1984). Academic integrity: Comparing faculty and student attitudes. Improving College and University Teaching, 32(3), 140-144. doi:10.1080/00193089.1984.10533862 
Pecorari, D. (2003). Good and original: Plagiarism and patchwriting in academic secondlanguage writing. Journal of Second Language Writing, 12(4), 317-345. doi:10.1016/j.jslw.2003.08.004

Rose, M. (1994). The author as proprietor: Donaldson $v$. Becket and the genealogy of modern authorship. In B. Sherman \& A. Strowel (Eds.), Of authors and origins: Essays on copyright law (pp. 23-56). Oxford, UK: Clarendon.

Sachar, C. O. (2018, April 18). Using Turnitin to teach students not to plagiarize. Inside Higher $E d$. Retrieved from http://insidehighered.com

Thompson, C. (2005). 'Authority is everything': A study of the politics of textual ownership. International Journal for Educational Integrity, 1(1). Retrieved from http://ojs.unisa.edu.au/index.php/IJEI

Weber-Wulff, D. (2014). False feathers: A perspective on academic plagiarism. Berlin, Germany: Springer.

Weber-Wulff, D. (2019). Plagiarism detectors are a crutch, and a problem. Nature, 567(7749), 435. doi:10.1038/d41586-019-00893-5 Retrieved from http://nature.com 